\title{
Students' Creative Thinking Skills on Heat Phenomena Using Pogil Learning Model
}

\author{
Rinta Dian Pratiwi ${ }^{*}$, Ashadi², Sukarmin ${ }^{3}$, Dewanto Harjunowibowo ${ }^{4}$ \\ 1, 2, 3 Master Program of Science Education, Sebelas Maret University, Surakarta, Indonesia \\ ${ }^{4}$ Faculty of Engineering, The University of Nottingham, Nottingham, United Kingdom \\ *Corresponding Address: rintadian01@student.uns.ac.id
}

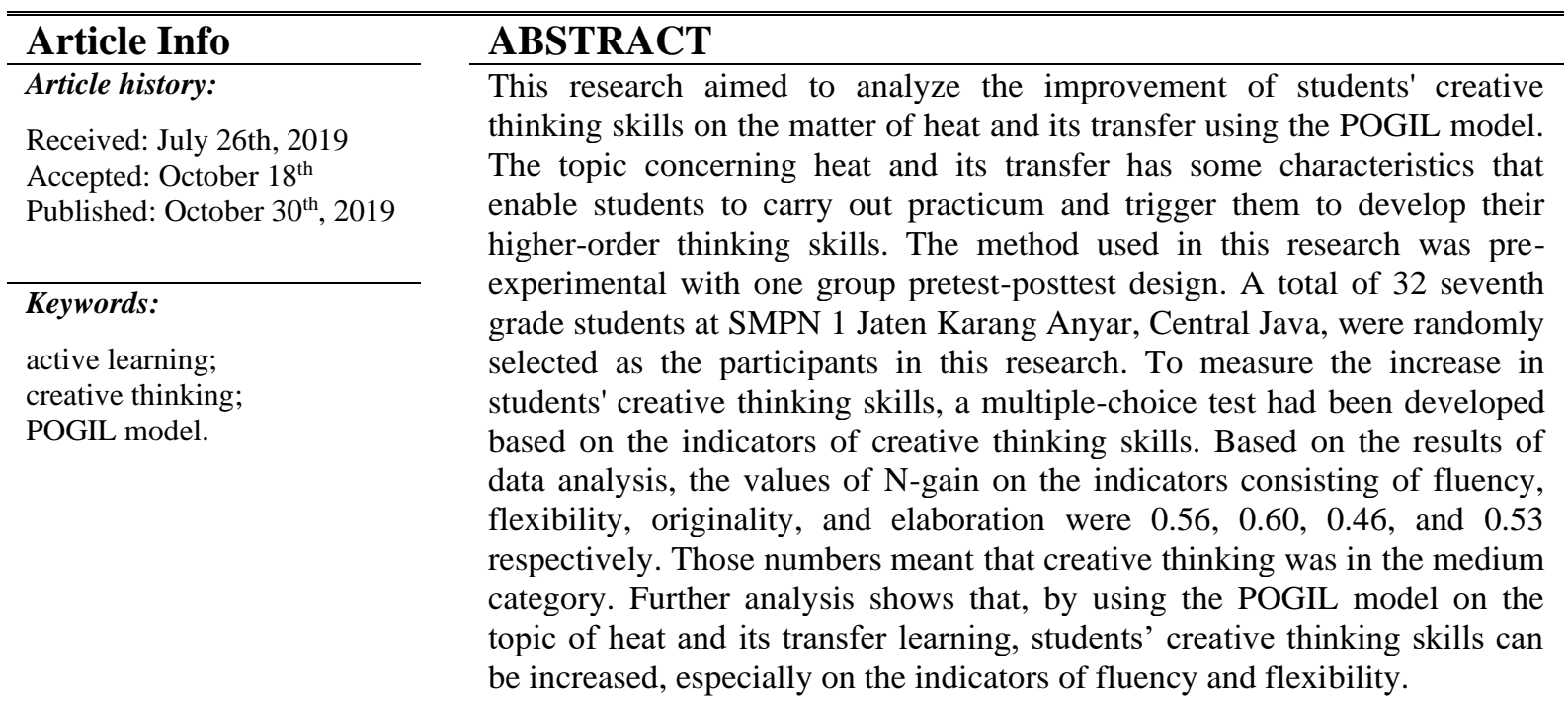

(C) 2019 Physics Education Department, UIN Raden Intan Lampung, Indonesia.

\section{INTRODUCTION}

The development of information, technology, and digitalization in the 4th era of the industrial revolution have created a new paradigm in education (21st-century learning). In the new era of education, teachers must be able to facilitate students to think critically and creatively and to have communication skills as well as good collaboration (Griffin et al. 2012; Shidiq \& Yamtinah, 2019; Trilling \& Fadel, 2009).

The focus of this research is to improve one of the skills needed by students in the 21 st century, namely creative thinking skills. According to Kampylis \& Berki (2014), creative thinking is defined as a thinking process that allows students to apply their imagination to produce ideas, formulate questions and hypotheses, conduct an experiment with alternatives, and evaluate ideas, processes, and final products. Creative thinking is essentially related to the discovery of something, and concerning the things that produce something new by using something that has already existed (Daryanto, 2009).

Creative thinking has many conceptualizations. Some experts see it as a process that occurs through stages. Other experts see creative thinking in terms of creative products and creative people. Some of those who see it as a process are Isaksen and Treffinger (Treffinger \& Isaksen, 2005); and Torrance (Phillips \& Torrance, 1976; Torrance, 1968, 1973; Torrance \& Aliotti, 1969; Torrance \& Hansen, 1965). They are experts in the fields of education and creativity (Freeman, 1999).

The term, creative thinking skills, refers to a constellation of general mental abilities 
that are considered a creative achievement. Many educators and psychologists prefer to call this ability "divergent thinking", "productive thinking", or "imagination". Some scientists prefer to use the term "creative " only to refer to a rare, particular, and substantive capacity (Torrance, 1968).

Creative itself is the process of being sensitive to problems, deficiencies, gaps in knowledge, missing elements, and disharmony; identifying difficulties; finding solutions, making predictions, or formulating hypotheses about deficiencies; testing and re-examining hypotheses and maybe modifying them; and finally communicating the results (Almeida et al., 2008; Kim, 2006; Torrance, 1968).

Creative thinking is still difficult to define in the context of natural science learning, but researchers believe that it is part of a cognitive process that can be developed through adequate learning design (Scott et al., 2004). Creative thinking skills can influence and be influenced by lots of aspects. The study conducted by Yanti (2016) showed that creative thinking skills can be improved through the application of problem-based learning (hereafter as PBL) model (Yang et al., 2016). However, Ayyildiz \& Tarhan, (2018) revealed some obstacles in the application of PBL model in that it requires more time to solve the problems, has difficulty in doing an objective assessment, and gives a great responsibility to the teacher, so that both teacher and students are expected to be familiar with the types of problems in PBL model (Ayyildiz \& Tarhan, 2018). Also, a digital learning module can be used by students in practicing problem-solving skills, but due to the limitation of students' facilities, this module is not effective for the use (Mulhayatiah et al., 2019).

Learning experiences gained in the classroom can be arranged depending on the scenario used by the teacher in accordance with the lesson plan (Faour, Hammoudeh, \& Ghamdi, 2012; King \& Bauer, 1986; Qureshi \& Ullah, 2014) Currently, various learning models are applied to help teachers to accommodate students in developing creative thinking skills, such as the use of contextual learning with module (Kurniasari, Sukarmin, \& Sarwanto, 2018) and project-based learning (Diawati et al., 2018). However, the model has not been focused on student activities in the classroom. Students who are actively involved in learning in the classroom to improve creative thinking skills are important. One of the solutions to overcome such problems is by applying the Process Oriented Guided Inquiry Learning (hereafter as POGIL) model. This model can get students involved in terms of activities and work together (Haryati, 2018; Walker \& Warfa, 2017).

This model is based on the principle of constructivism which can trigger students to actively learn through interactions in groups to solve problems. According to Hanson, D. (2010) POGIL is student-centered learning and group-work or teamwork learning to master concepts but not memorizing. The study conducted by Rosadi et al., (2018) showed that the natural science learning model grounded in POGIL can improve analytical thinking skills and students' learning outcomes. With this model, students can develop creative thinking skills, metacognition, communication, teamwork, and management. The teacher's task in learning only provokes students to solve problems and do things to practice their creativity. Therefore, it becomes a novelty that differs from previous researches to use the POGIL model in learning physics to improve students' creative thinking skills. This is offered as an answer to the problems that have been identified previously.

Specifically, the purposes of this study are to analyze the improvement of students' creative thinking skills on the topic of heat and its transfer using the POGIL model. This research is expected to contribute to the novelty of the teacher learning model to improve students' creative thinking skills on the topic of heat and its transfer. 


\section{METHODS}

\section{Research design}

The method used in this research was a pre-experimental method with one group pretest-posttest only design (Fraenkel, 2012). The selection of the research method was based on the learning objective intended to quantitatively analyze the improvement of the creative thinking skills of junior high school students. The research flows can be seen in Figure 1.

This research began with the identification of problems, preliminary research to find the best way to deal with the problems, and implementation of the alternative solution proposed. This research focused on the assessment of students' creative thinking skills on the heat and its transfer topic. Subsequently, the POGIL learning model was applied during several meetings. At the end of the lesson, the test was given again to see the improvement of students' creative thinking skills. The design of the chosen research method can be seen in Table 1.

Table 1. Research design

\begin{tabular}{ccc}
\hline Pretest & Treatment & Posttest \\
\hline $\mathrm{X}_{1}$ & POGIL Model & $\mathrm{X}_{2}$ \\
\hline
\end{tabular}

\section{Research participants and locations}

The sample selection technique used in this research was random sampling so that 32 junior high school students in grade VII were obtained as the samples. The research was conducted at SMPN 1 Jaten, Karanganyar, Central Java.

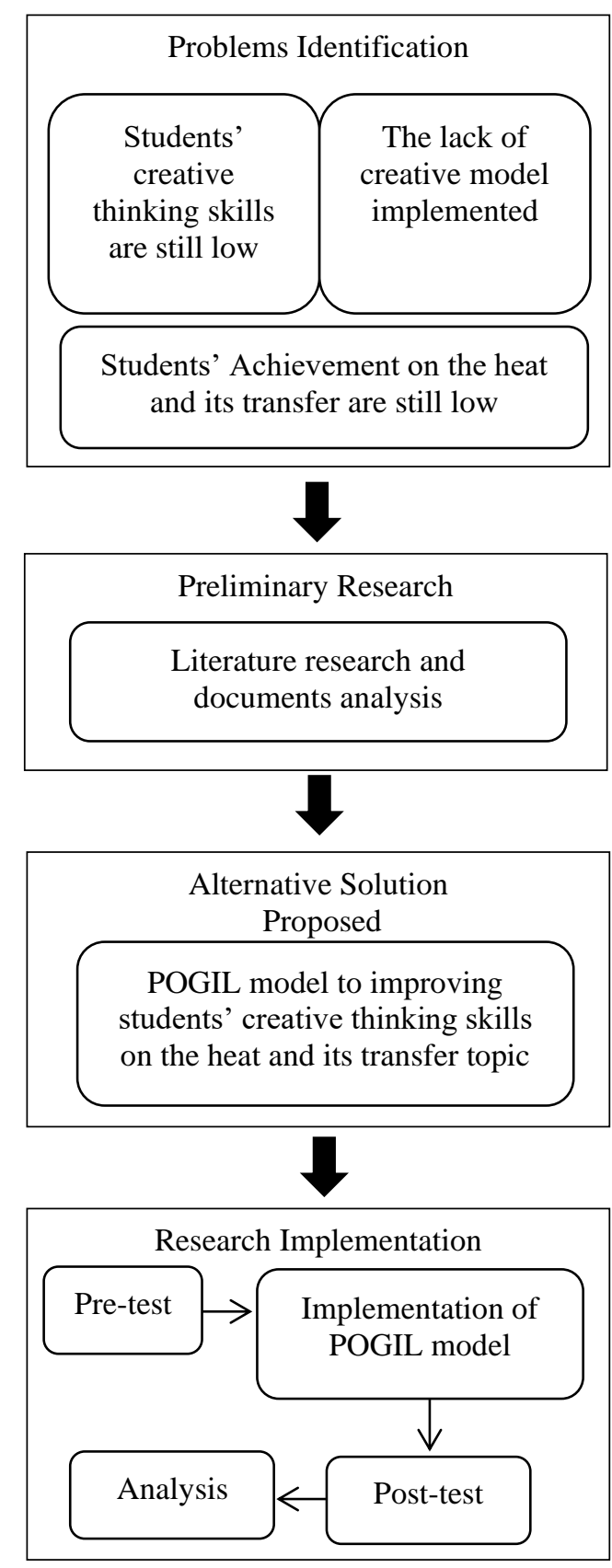

Figure 1. Research flow

\section{Instrument}

The quantitative data in this research were garnered from the use of multiplechoice test instruments to measure the improvement of students' creative thinking skills. The instruments used were 10 items on the topic of heat and its transfer. The indicators of creative thinking skills used were adapted from Guilford (Guilford, 1988) that entailed; 
a. Fluent thinking (Fluency); the ability to generate many ideas, answers, problemsolving, or questions.

b. Flexible thinking (Flexibility); the ability to generate various ideas from information that has been obtained.

c. Original thinking (originality); the ability to generate notions or ideas that are new and different from the prior ones.

d. Elaborate thinking (elaboration); the ability to develop and add ideas in detail so that they become more interesting.

\section{Data analysis technique}

The technique of data analysis was undertaken by tabulating the data that had been obtained, then calculating the percentage score of each component of the questions consisting of 10 questions with regard to creative thinking skills having been given to 32 students of class VII, and then calculating the percentage score of each aspect by using the following formula:

$$
\text { Ps }=\frac{N i}{N}
$$

$P S$ is the percentage score; $\mathrm{Ni}$ is the number of scores obtained, and $\mathrm{N}$ is the maximum number of the score for each aspect. The results of the percentage score of each component are indicated by criteria according to Shriki (2013). This category is shown in Table 2:

Table 2. Criteria for average values in creative thinking profile scores

\begin{tabular}{cc}
\hline Percentage & Category \\
\hline$<55 \%$ & Low \\
$\leq 55 \%-\leq 75 \%$ & Medium \\
$>75 \%$ & High \\
\hline
\end{tabular}

The analysis used to determine the effectiveness or increase (gain) of the creative thinking skills of the students whose learning processes applied the POGIL model was Gain score. The gain score is also called a score increase or difference that indicates the difference between the pretest and posttest scores in one sample group. Meltzer, D.E. (2002) states that the Gain scores can be obtained by using the following formula:

$$
N-\text { Gain }=\frac{\text { Tpost }-T_{\text {pre }}}{T_{\text {maks }}-T_{\text {pre }}}
$$

$\mathrm{T}_{\text {post }}$ is average posttest score; $\mathrm{T}_{\text {pre }}$ is the average pretest score, and $\mathrm{T}_{\max }$ is the maximum ideal score. The $\mathrm{N}$-gain score obtained from the formula above can be categorized using the gain score interpretation table conforming to Table 3 .

Table 3. N-gain category

\begin{tabular}{cc}
\hline $\mathbf{N}$-gain $(\mathrm{g})$ & Category \\
\hline$(\mathrm{g})>0,7$ & High \\
$0,3<(\mathrm{g}) \leq 0,7$ & Medium \\
$(\mathrm{g}) \leq 0,3$ & Low \\
\hline
\end{tabular}

\section{RESULTS AND DISCUSSION}

The purpose of this study was to analyze the improvement of students' creative thinking skills on the topic of heat and its transfer using the POGIL model. The POGIL model was implemented with the syntax developed by Hanson, D. (2006) as shown in Table 4. In the meantime, the creative thinking skills used in this research referred to Guilford (Guilford, 1988)

Some of the main frameworks that have been established in creative thinking skills include the creative thinking framework proposed by Guilford, Perkins, and Torrance (Guilford, 1988; Perkins, 1984; Sadlersmith, 2014; Torrance, 1961). This research adopted Guilford's creative thinking skills. Aside from being in line with this research objective, this framework also has several advantages including having a complete description of creative thinking, namely operations, content, and production (Anoiko, 2011) and distinguishing between convergent and divergent thinking processes (Anoiko, 2011; Costa, 1991).

The data on students' creative thinking skills were obtained by giving 10 multiplechoice test items in which each represented 4 aspects of creative thinking skills. The example of a critical thinking instrument is 
presented in Table 5. Differences in scores obtained by students before and after learning using the POGIL model are presented in Table 6 .

Table 4. Process-oriented guided inquiry learning (POGIL) syntax

\begin{tabular}{lll}
\hline No & \multicolumn{1}{c}{ Syntax } & \multicolumn{1}{c}{ Activity Components } \\
\hline 1 & Identification of learning needs & $\begin{array}{l}\text { An interesting issue is presented. An answer to the } \\
\text { question formulation of the problem is given. } \\
\text { Learning objectives and competency indicators are } \\
\text { defined. }\end{array}$ \\
\hline 2 & Linking prior knowledge & $\begin{array}{l}\text { A question on the issue is raised and students } \\
\text { predict the answer. Prerequisite material is defined. }\end{array}$ \\
\hline 3 & Exploration & $\begin{array}{l}\text { A model and assignment are given, and the source } \\
\text { of the material is defined. Students explore models } \\
\text { or assignments in response to critical thinking. }\end{array}$ \\
\hline 4 & Understanding and concept formation & $\begin{array}{l}\text { Critical thinking questions will lead to identifying } \\
\text { and understanding concepts to be built. }\end{array}$ \\
\hline 5 & The practice of applying knowledge & $\begin{array}{l}\text { Students work on problems to apply directly from } \\
\text { the knowledge and concepts gained. }\end{array}$ \\
\hline 6 & Applying knowledge to new contexts & $\begin{array}{l}\text { Students work on problems with different contexts } \\
\text { and higher levels. }\end{array}$ \\
\hline 7 & Reflection in process & $\begin{array}{l}\text { The completion of the problem and the answer to } \\
\text { the question are validated and integrated with the } \\
\text { concepts and performance of students during } \\
\text { learning assessed. }\end{array}$ \\
\hline
\end{tabular}

Table 5. The example of creative thinking instrument

\begin{tabular}{|c|c|c|}
\hline $\begin{array}{c}\text { Basic Aspect of } \\
\text { Creative Thinking }\end{array}$ & Indicator & Question \\
\hline $\begin{array}{l}\text { The authenticity of } \\
\text { hinking (originality) }\end{array}$ & $\begin{array}{l}\text { Providing ideas } \\
\text { for finding new } \\
\text { solutions related } \\
\text { to heat and its } \\
\text { transfer }\end{array}$ & $\begin{array}{l}\text { Provided: glass bottles, plastic bottles, bamboo, cloth, } \\
\text { cork. } \\
\text { If you don't have a flask, how do you make a mock-up of a } \\
\text { flask from the device provided so you can store hot water } \\
\text { for a long time? } \\
\text { a. load a flask from a plastic bottle, put it in bamboo until } \\
\text { there are no gaps between the two, and make the lid from } \\
\text { the cork } \\
\text { b. make a flask from a glass bottle, put it in bamboo until } \\
\text { there is no gap between the two, and make it from cork } \\
\text { c. make a flask from a glass bottle, put it in bamboo and } \\
\text { make a gap between the two, insert a cloth between the } \\
\text { glass walls, and cover it with cork } \\
\text { d. make a flask from a plastic bottle, put it in bamboo and } \\
\text { make a gap between the two, insert a cloth between the } \\
\text { glass walls, and cover it with cork }\end{array}$ \\
\hline
\end{tabular}

Table 6. Descriptive statistics of the obtained scores of students' creative thinking skills

\begin{tabular}{|c|c|c|c|c|c|c|c|c|}
\hline \multirow{3}{*}{$\begin{array}{l}\text { Descriptive } \\
\text { statistics }\end{array}$} & \multicolumn{4}{|c|}{ Pretest } & \multicolumn{4}{|c|}{ Posttest } \\
\hline & \multicolumn{4}{|c|}{ Aspect } & \multicolumn{4}{|c|}{ Aspect } \\
\hline & $\mathbf{A}$ & $\mathbf{B}$ & $\mathbf{C}$ & D & $\mathbf{A}$ & $\mathbf{B}$ & $\mathbf{C}$ & D \\
\hline Total score & 58 & 34 & 25 & 24 & 97 & 52 & 43 & 45 \\
\hline Maximum score & 128 & 64 & 64 & 64 & 128 & 64 & 64 & 64 \\
\hline Percentage & $45 \%$ & $53 \%$ & $39 \%$ & $37 \%$ & $76 \%$ & $81 \%$ & $67 \%$ & $70 \%$ \\
\hline Category & Low & Low & Low & Low & High & High & Medium & Medium \\
\hline
\end{tabular}

Note: A: Fluency; B: Flexibility; C: Originality; D: Elaboration 
In general, Table 5 shows the scores in every aspect of creative thinking obtained by students before and after they were taught by using the POGIL model. Before the POGIL model was applied the students' creative thinking skills were in a low category, and after the POGIL model was applied, the students' creative thinking skills were in the medium and high categories. The increase in students' creative thinking skills was due to the application of the learning model that provided opportunities for students to think. POGIL model applied three learning cycles composed of exploration, discovery or formation of concepts, and application.

In the POGIL model, students were also facilitated in implementing their knowledge through problems, learning to communicate, and most importantly being able to do a reflection process to improve their process skills. Hence, the POGIL model was considered capable of accommodating students in developing creative thinking skills. This can be seen in Figure 2.

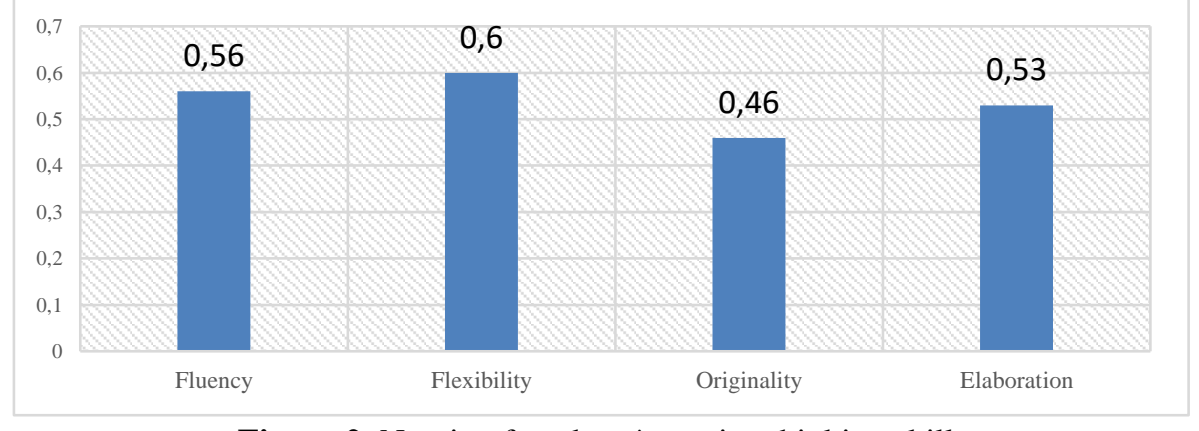

Figure 2. N-gain of students' creative thinking skills

The value shown in the graph indicates that the obtained $\mathrm{N}$-gain for each aspect was in the medium category. This meant that through the POGIL model, students' creative thinking skills could adequately be developed. The Fluency aspect had an Ngain value of 0.56 .

The fluency aspect allowed us to assess the students' ability to come up with ideas, be able to propose many answers, and be able to put forward problem-solving. On the topic of heat and its transfer, the teacher presented the example of a problem about how it was that if traveling during the day, the students would not feel hot. The answers and solutions to this question reflected on the aspect of fluency because students were required to provide their ideas along with the supporting reasons.

The aspect of flexibility would be observed when students were able to see a problem from more than one point of view, and when they were able to link other disciplines to solve the problem at hand. Based on the $\mathrm{N}$-gain value, this aspect had the highest value. That was because the POGIL model presented students with problems, and they could be solved in more than one way.

The aspect of originality referred to how students presented innovative problemsolving. Innovation from students' problem solving could be a modification of whatever existed or a presentation of something completely new. The aspect of originality had the lowest $\mathrm{N}$-gain value because students found it difficult to create the solutions that had never been expressed before. However, this ability could still be honed because the POGIL model allowed students to explore and reflect on activities. Both of these activities could spur students to create new solutions.

The Elaboration aspect was an aspect of creative thinking that required students to enrich and explain in more detail the proposed solutions. POGIL invited students to think creatively starting from observing, hypothesizing, identifying models in the form of practicum about heat and its 
transfer, analyzing, and concluding through practicum activities.

Guided practice can improve students' ability to understand arguments and problems oriented towards certain abilities (Latifah, 2016). The use of practical tools in learning can also attract students' interest (Agustini. R \& Suyatna, 2018; Wardani, $\mathrm{Y}, \mathrm{R}, 2019)$. The application of the POGIL model is in accordance with the opinion of Doppelt, (2003) regarding active learning in constructivism-based teaching, whereby students will find it easier to find out and to understand concepts through active thinking and problem solving, and that the students learn in the realms of not only remembering but also conducting knowledge-building activities with exercises given by the teacher or homework contained in books (Doppelt, 2009). Students are responsible for learning events and learning outcomes. This is in line with the opinion expressed by Triwiyono, (2011), in that learning with guided experiments is more effective in improving students' higher-order thinking skills compared to conventional learning. The other study result which is in line indicates that laboratory inquiry can improve students' mastery of concepts and creative thinking skills (Suparman \& Husen, 2015).

The POGIL model spurs the development of students' self-regulation (Şen \& Y1lmaz, 2015). The ability to work together is also homed in this model. The collaboration is formed through teamwork to identify and develop knowledge through data testing.

In this research, when learning took place, a team consisting of four students was formed. Each team comprised a manager, spokesperson, recorder, and strategy analyst. Each member had their respective duties. The aim was to improve the ability to work together in a team, work critically, be responsible, exchange opinions, draw conclusions, and solve problems. The group structure was carried out for each meeting. Collaboration between students will make them actively involved individually and also in group work (Sarwi \& Liliasari, 2009). A similar notion is conveyed by Brown $\mathrm{S}$. (2010) saying that the function of one's self-selected by the team to solve questions helps develop the key process skills such as critical thinking and communication.

Researchers have conducted many other studies to improve creative thinking skills, such as the use of worksheet and modules (Klieger \& Sherman, 2015; Romli et al., 2018), the use of inquiry learning models, STEM (Li et al., 2018), project-based learning (Diawati et al., 2018; Mihardi et al., 2013), and problem-based learning (Yoon et al., 2015). The use of PBL and other models has been carried out by other researchers to improve students' creative thinking skills. However, the POGIL model, besides being able to improve students' creative thinking skills, it also makes all students actively involved in the learning process. This is the difference between this research and other studies.

The use of the POGIL model makes students happier, and they come to understand the things that often exist in everyday environments, for instance, the things about how to use a thermometer and stopwatch. Students learn with hands-on activities. Thus, students' scientific activities can influence their psychomotor development. The application of the physics learning model based on hands-on activities can foster the ability to think creatively, and it is demonstrated during learning (Yuliati, 2011).

\section{CONCLUSION}

Based on the results of data analysis, the values of $\mathrm{N}$-gain on the indicators which consist of fluency, flexibility, originality, and elaboration are $0.56,0.60,0.46$ and 0.53 respectively. Those numbers mean that creative thinking is in the medium category. Further analysis shows that, by using the POGIL model on the topic of heat and its transfer learning, students' creative thinking 
skills can be increased, especially on the indicators of fluency and flexibility.

\section{AUTHOR CONTRIBUTIONS}

RD makes research instruments and designs research. AH and SR collected data on site and compiled research results. DH performs statistical calculations. RD and SR analyze the data and make discussions.

\section{REFERENCES}

Agustin, R., Liliasari, L., Winarno, N., \& Widodo, A. (2017). Investigating PreService Science Teachers (PSTs)' Technological Pedagogical Content Knowledge Through Extended Content Representation (CoRe). Journal of Physics: Conference Series, (812 012103). https://doi.org/10.1088/17426596/755/1/011001

Almeida, L. S., Prieto, L., Ferrando, M., Oliveira, E., \& Ferr, C. (2008). Torrance Test of Creative Thinking: The Question of Its Construct Validity. Thinking Skills and Creativity, 3, 5358.

https://doi.org/10.1016/j.tsc.2008.03.00 3

Al-Mandeel, H. M., Sagr, E., Sait, K., Latifah, H. M., Al-Obaid, A., AlBadawi, I. A., ... \& BrignardelloPetersen, R. (2016). Clinical practice guidelines on the screening and treatment of precancerous lesions for cervical cancer prevention in Saudi Arabia. Annals of Saudi medicine, 36(5), 313-320.

Anoiko. (2011). Creativity. Retrieved from https://oiko.files.wordpress.com/2011/0 3/2011_wiki_anoiko_creativity1.pdf

Ayyildiz, Y., \& Tarhan, L. (2018). ProblemBased Learning in Teaching Chemistry: Enthalpy Changes in Systems. Research in Science and Technological Education, 36(1), 3554.

https://doi.org/10.1080/02635143.2017. 1366898

Brown S. (2010). A Process-oriented
Guided Inquiry Approach to Teaching Medicinal Chemistry. American Journal of Pharm Educ , 74 (7). (2010), 74, 2010.

Chen, C., \& Song, M. (2017). Representing Scientific Knowledge: the Role of Uncertainty. Representing Scientific Knowledge: The Role of Uncertainty, (November), $1-375$. https://doi.org/10.1007/978-3-31962543-0

Costa, A. L. (1991). Developing Minds. Alexandria: Association for Supervision and Curriculum Development.

Daryanto. (2009). Panduan Proses Belajar Kreatif dan Inovatif. Jakarta:AV Publisher.

Diawati, C., Liliasari, Setiabudi, A., \& Buchari. (2018). Using Project-Based Learning to Design, Build, and Test Student-Made Photometer by Measuring the Unknown Concentration of Colored Substances. Journal of Chemical Education, 95(3), 468-475. https://doi.org/10.1021/acs.jchemed.7b 00254

Doppelt, Y. (2009). Assessing Creative Thinking in Design-Based Learning, 55-65. https://doi.org/10.1007/s10798006-9008-y

Faour, H., Hammoudeh, M., \& Ghamdi, A. Al. (2012). Enhancing Student Learning Experience and Satisfaction Using Virtual Learning Environments. 2012 International Conference on Education and E-Learning Innovations, ICEELI 2012, (July), 11-13. https://doi.org/10.1109/ICEELI.2012.6 360588

Fraenkel. (2012). How to Design and Evaluate Research in Education. New York: Mc Graw Hill.

Freeman, K. A. (1999). Inviting Critical and Creative Thinking into the Classroom. Boston: University of Massachusetts Boston.

Griffin, P., Care, E., \& McGaw, B. (2012). Assessment and Teaching of 21st 
Century Skills. (P. Griffin, B. McGaw, \& E. Care, Eds.). Dordrecht: Springer Netherlands.

https://doi.org/10.1007/978-94-0072324-5

Guilford, J. P. (1988). Some Changes in the Structure-of-Intellect Model. Educational and Psychological Measurement, 48. Retrieved from https://oiko.files.wordpress.com/2011/0 3/2011_wiki_anoiko_creativity1.pdf

Hanson, D. (2010). Instructor's Guide to Process-Oriented Guided-Inquiry Learning. (pp. 1- 54). New York: Department of Chemistry Stony Brook University.

Haryati, S. (2018). The Effectiveness of the Process Oriented Guided Inquiry Learning (POGIL) Model in Educational Psychology Learning. International Journal of Pedagogy and Teacher Education, 2(2), 375. https://doi.org/10.20961/ijpte.v2i2.240 94

Kampylis, P., \& Berki, E. (2014). Nurturing Creative Thinking. Educational Practices Series-25.

Katz, J., \& Anderson, R. C. (2018). A Review of Articles Using Observation Methods to Study Creativity in Education (1980- 2018). Journal of Creative Behavior, O(0), 1-17. https://doi.org/10.1002/jocb.385

Kim, K. H. (2006). Can We Trust Creativity Tests? A Review of the Torrance Tests of Creative Thinking (TTCT). Creativity Research Journal, 18(1), 314.

King, P. M., \& Bauer, B. A. (1986). Leadership Issues for NontraditionalAged Women Students. In Empowering Women: Leadership Development Strategies on Campus (pp. 77-88). San Francisco.

Klieger, A., \& Sherman, G. (2015). Physics Textbooks: Do They Promote or Inhibit Students ' Creative Thinking. Journal of Physics: Conference Series,
$50(3)$,

305.

https://doi.org/10.1088/0031-

9120/50/3/305

Kurniasari, H., Sukarmin, \& Sarwanto. (2018). Development of Contextual Teaching and Learning Based Science Module for Junior High School for Increasing Creativity of Students. Journal of Physics: Conference Series, 983(1). https://doi.org/10.1088/17426596/983/1/012035

Li, W., Li, G., Mo, W., \& Li, J. (2018). The Influence of STEAM Education on the Improvment of Students' Creative Thinking. Advances in Social Science, Education and Humanities Research, 232, 924-927. https://doi.org/10.2991/icadce18.2018.200

Meltzer, D.E. (2002). The Relationship between Mathematics Preparation and Conceptual Learning Grains in Physics: A Possible "Hidden Variable" in Diagnostice Pretest Scores. American Journal Physics, 70 (12).

Mihardi, S., Harahap, M. B., \& Sani, R. A. (2013). The Effect of Project Based Learning Model with KWL Worksheet on Student Creative Thinking Process in Physics Problems. Journal of Economics and Sustainable Development ISSN, 4(18), 93-107.

Mulhayatiah, D., Purwanti, P., Setya, W., Suhendi, H. Y., Kariadinata, R., \& Hartini, S. (2019). The Impact of Digital Learning Module in Improving Students' Problem-Solving Skills. Jurnal Ilmiah Pendidikan Fisika AlBiruni, 8(1), 11-22. https://doi.org/10.24042/jipfalbiruni.v8 i1.3150

Perkins, D. N. (1984). Creativity by Design. Educational Leadership.

Phillips, V. K., \& Torrance, E. P. (1976). Originality on the Rorschach Ink Blot Test and The Creative Personality. The Journal of Creative Behavior, II(2), 30602. 
Qureshi, S., \& Ullah, R. (2014). Learning Experiences of Higher Education Students: Approaches to Learning as Measures of Quality of Learning Outcomes. Bulletin of Education and Research, 36(1), 79-100.

Ratnasari, D., Sukarmin, S., Suparmi, S., \& Aminah, N. S. (2017). Students' Conception on Heat and Temperature toward Science Process Skill. Journal of Physics: Conference Series, 895(1). https://doi.org/10.1088/17426596/895/1/012044

Romli, S., Abdurrahman, \& Riyadi, B. (2018). Designing Students' Worksheet Based on Open- Ended Approach to Foster Students' Creative Thinking Skills. Journal of Physics: Conference Series, 012050. https://doi.org/10.1088/17426596/948/1/012050

Rosadi, I., Maridi, M., \& Sunarno, W. (2018). The Effectiveness of ProcessOriented Guided Inquiry Learning to Improve Students' Analytical Thinking Skills on Excretory System Topic. Biosaintifika: Journal of Biology \& Biology Education, 10(3), 684-690. https://doi.org/10.15294/biosaintifika.v 10i3.15990

Sadler-smith, E. (2014). Wallas' four-stage model of the creative process: More than meets the eye? University of Surrey.

Sarwi, \& Liliasari. (2009). Penerapan KJTP: Vol.07, No.01/Juli 2019/hal: 45 5656 Strategi Kooperatif Dan Pemecahan Masalah Pada Konsep Gelombang Untuk Mengembangkan Keterampilan Berfikir Kritis. Pendidikan Fisika Indonesia, 5, 90-95.

Şen, Ş., \& Y1lmaz, A. (2015). the Effects of Process Oriented Guided Inquiry Learning Environment on Students' Self-Regulated Learning Skills. Problems of Education in the 21st Century, 66(January), 54-66.

Scott, G., Leritz, L. E., \& Mumford, M. D. (2004). The effectiveness of creativity training: A quantitative

review. Creativity

Research

Journal, 16(4), 361-388.

Shidiq, A. S., \& Yamtinah, S. (2019). PreService Chemistry Teachers' Attitudes and Attributes toward The TwentyFirst Century Skills. In Journal of Physics: Conference Series (Vol. 1157). https://doi.org/10.1088/17426596/1157/4/042014

Subekti, J. (2015). Pengaruh Active Learning untuk Meningkatkan Aktivitas Belajar Siswa pada Materi Pemanasan Global. E Journal UNILA.

Suparman, S., \& Husen, D. N. (2015). Peningkatan kemampuan berpikir kreatif siswa melalui penerapan model problem based learning. Jurnal Bioedukasi, 3(2).

Torrance, E. P. (1961). Priming Creative Thinking in the Primary Grades. Chicago Journal, 62(1), 34-41.

Torrance, E. P. (1968). Examples and Rationales of Test Tasks for Assessing Creative Abilities. International Workshop on Possibilities and Limitations of Educational Testing, 2(3), 165-178.

Torrance, E. P. (1973). Non-Test Indicators of Creative Talent Among Disadvantaged Children.

Torrance, E. P., \& Aliotti, N. C. (1969). Sex Differences in Levels of Performance and Test-Retest Reliability on the Torrance Tests of Creative Thinking. The Journal of Creative Behavior, 3(1), 52-57.

Torrance, E. P., \& Hansen, E. (1965). The Question-Asking Behavior of Highly Creative and Less Creative Basic Business Teachers Identified By a Paper And-Pencil Test. Psychological Report, 17, 815-818.

Treffinger, D. J., \& Isaksen, S. G. (2005). The History, Development, and Implications for Gifted Education and Talent Development. Gifted Child Quarterly, 49(4).

Trilling, B., \& Fadel, C. (2009). 21st 
Century Skills. San Francisco: John Wiley \& Sons.

Triwiyono. 2011. Program Pembelajaran Fisika Menggunakan Metode Eksperimen Terbimbing untuk Meningkatkan Keterampilan Berpikir Kritis. Jurnal Pendidikan Fisika Indonesia. 7, 80- 83. (2011), 2011.

Walker, L., \& Warfa, A. R. M. (2017). Process Oriented Guided Inquiry Learning (POGIL) Marginally Effects Student Achievement Measures but Substantially Increases the Odds of Passing a Course. PLoS ONE, 12(10), $1-17$.

https://doi.org/10.1371/journal.pone.01 86203

Wulandari, R. ., \& Dkk. (2015). Instumen Two Tier Test Aspek Pengetahuan untuk Mengukur Ketrampilan Proses Sains (KPS) pada Pembelajaran Kimia untuk Siswa SMA/MA Kelas XI. Jurnal Pendidikan Kimia (JPK), 4(4), 147-155.

Yang, K. K., Lee, L., Hong, Z. R., \& Lin, H. S. (2016). Investigation of Effective
Strategies for Developing Creative Science Thinking. International Journal of Science Education, 38(13), 2133-2151.

https://doi.org/10.1080/09500693.2016. 1230685

Yanti. (2016). Pengembangan Modul Berbasis Guided Inquiry Laboratory (GIL) untuk Meningkatkan Literasi Sains Dimensi Konten. Jurnal Inkuiri, 5(2252-7893), 105-111.

Yoon, H., Woo, A. J., Treagust, D. F., \& Chandrasegaran, A. L. (2015). SecondYear College Students, Scientific Attitudes and Creative Thinking Ability : Influence of a Problem-Based Learning (PBL) Chemistry Laboratory Course. Affective Dimensions in Chemistry Education, 217-233. https://doi.org/10.1007/978-3-66245085-7_11

Yuliati. 2011. Pembelajaran Fisika Berbasis Hands on Activities untuk Menumbuhkan Kemampuan Berpikir Kritis dan Meningkatkan Hasil. (2011), 2011. 